\title{
NGF Induces Neonatal Rat Sensory Neurons to Extend Dendrites in Culture after Removal of Satellite Cells
}

\author{
Paul De Koninck, ${ }^{1}$ Salvatore Carbonetto, ${ }^{1,2,3}$ and Ellis Cooper ${ }^{2}$ \\ Departments of 'Biology and PPhysiology and ${ }^{3}$ Center for Research in Neuroscience, McGill University, Montréal, Québec, \\ Canada H3G 1 Y6
}

\begin{abstract}
Vertebrate sensory neurons have a pseudo-unipolar morphology; their somata are covered by satellite cells and lack dendrites or synaptic contacts. However, when neonatal rat sensory neurons from the nodose ganglia develop in culture in absence of satellite cells and with NGF, they form synapses among themselves. In this study, we investigated whether neonatal rat nodose neurons express dendrites under the same culture conditions. We show by Lucifer yellow injection that nodose neurons remain typically unipolar when cocultured with their ganglionic satellite cells. However, when these neurons are cultured without satellite cells, virtually all neurons acquire a multipolar morphology. Moreover, when NGF is added to satellite cell-free cultures, several neurons extend dendrites; these processes stain positively for $\mathrm{mi}-$ crotubule-associated protein-2. NGF induces a 17-fold increase in dendritic outgrowth after 3 weeks but has little effect on axon number. In addition, we find that the ability of nodose neurons to extend dendrites is developmentally regulated. Furthermore, in a combined morphological and electrophysiological study, using whole-cell voltage-clamp technique with Lucifer yellow in the recording solution, we demonstrate a positive correlation between the extent of dendritic outgrowth and the density of ACh currents, suggesting that these dendrites have ACh receptors.

Our results indicate that neonatal rat nodose neurons are capable of extending dendrites and that extrinsic factors can induce or suppress their extension. In addition, the results suggest that these dendrites may act as principal postsynaptic structures for synapse formation that occurs in these cultures.
\end{abstract}

[Key words: dendrite, sensory neuron, NGF, satellite cell, ACh receptor, synapse formation]

An important aspect in understanding how synaptic connections are established, maintained, and modified is to understand what controls the growth of dendrites. CNS neurons in vertebrates typically have several dendrites that originate from their cell bodies, and most afferents establish synapses on these dendrites (Peters et al., 1991). Little is known, however, about the mechanisms that stimulate or inhibit the initiation of dendrites, or

\footnotetext{
Received May 1, 1992; revised Aug. 6, 1992; accepted Aug. 14, 1992.

We thank B. Pie for technical assistance, and Drs. K. S. Kosik and J. Diamond for their generous gift of antibodies, against MAP2(R4) and NGF, respectively. This work was supported by MRC of Canada and FRS du Québec. P.D.K. is supported by a doctoral fellowship from NSERC of Canada.

Correspondence should be addressed to Dr. Ellis Cooper, Department of Physiology, McGill University, McIntyre Medical Building, Room 1127, 3655 Drummond Street, Montréal, Québec, Canada H3G 1 Y6.

Copyright $(1993$ Society for Neuroscience $0270-6474 / 93 / 130577-09 \$ 05.00 / 0$
}

what controls the arborization of dendrites once they have been initiated. Recent studies have indicated that the initiation of dendrites is, in part, governed by mechanisms intrinsic to neurons (Dotti et al., 1988; Black and Baas, 1989). In addition, there is ample evidence that extrinsic factors influence neuronal polarity and dendritic arborization (Mudge, 1984; Bruckenstein and Higgins, 1988a,b; Purves et al., 1988; Snider, 1988; Tropea et al., 1988; Chamak and Prochiantz, 1989; Johnson et al., 1989; Lein and Higgins, 1989; Clendening and Hume, 1990; Schilling et al., 1991).

While almost all vertebrate neurons extend dendrites, a notable exception are peripheral sensory neurons. Morphologically, sensory neurons are pseudo-unipolar, and their ovoid somata, which are devoid of synapses, are covered by satellite cells (perisomatic glia) and lack dendrites (Lieberman, 1976; Pannese, 1981). The axons of sensory neurons bifurcate shortly after emerging from the cell body: one branch grows peripherally and its terminals develop into a sensory transducer; the other branch grows centrally, forming synaptic connections within the CNS. The fact that sensory neurons do not express typical axonaldendritic polarities, like those established on most neurons, suggests that either some of the mechanisms that initiate dendritic growth are not functioning in sensory neurons, or mechanisms exist that actively suppress sensory neurons from extending dendrites. Deciding between these two possibilities should provide some clues as to the mechanisms that control the establishment of neuronal polarity.

Previously, it was shown that when neonatal sensory neurons from rat nodose ganglia were cultured in absence of satellite cells, they formed synapses among one another (Cooper, 1984), suggesting that these neurons were expressing new postsynaptic elements necessary for synapse formation. Neuronal nicotinic $\mathrm{ACh}$ receptors are one example of these new postsynaptic elements that nodose neurons expressed under these culture conditions. In vivo, few nodose neurons express ACh currents, yet in these cultures, the majority had high-density ACh currents and indeed the synapses that formed were cholinergic (Cooper, 1984; Mandelzys and Cooper, 1992). Other possible postsynaptic spccializations that could be expressed on these neurons, and play a role in promoting these novel synapses among sensory neurons, are dendrites. If dendrites were being expressed de novo on these neurons, this preparation would provide an attractive model to investigate various mechanisms that control dendritic outgrowth, as well as targeting and localization of postsynaptic elements (e.g., ACh receptors) and nerve terminals in neuronneuron synapses.

To investigate whether nodose neurons have dendrites, one needs a reliable marker to distinguish dendrites from axons as the neurons develop in culture. There are several notable dif- 
ferences in the intracellular composition of axons and dendrites; for example, (1) ribosomes and Golgi elements are present in dendrites but not in axons (Bartlett and Banker, 1984a,b), (2) the microtubule polarity orientation differs in axons and dendrites (Black and Bass, 1989), (3) a much greater number of neurofilaments are phosphorylated in axons compared to dendrites (Peng et al., 1986), and (4) the types of microtubuleassociated proteins differ in axons and dendrites (Kosik and Finch, 1987; reviewed by Matus, 1988). In particular, microtubulc-associated protein-2 (MAP2) and the mRNA that codes for it are found exclusively in cell bodies and dendrites (Carceres et al., 1984, 1986; Kosik and Finch, 1987; Kleiman et al., 1990) whereas tau proteins are predominantly distributed in axons (Kosik and Finch, 1987).

In this study, we have used antibodies to MAP2 to investigate whether neonatal sensory neurons from rat nodose ganglia extend dendrites when they develop in culture. Our experiments demonstrate that these sensory neurons are capable of extending dendrites under certain culture conditions, and they provide evidence for two factors that control dendrite outgrowth by these neurons: NGF promotes the initiation and arborization of dendrites, whereas ganglionic satellite cells override the NGF effect and thereby prevent dendrite formation on these neurons.

\section{Materials and Methods}

Cell cultures. Rat nodose and superior cervical ganglion (SCG) neurons were cultured as previously described (Cooper and Lau, 1986; McFarlane and Cooper, 1992). Briefly, nodose and SCG ganglia were dissected under sterile condition from postnatal day 1 (PI) or P14 rats (C.D. strain, Charles River, St. Constant, Québec, Canada) that were killed by cervical dislocation. The ganglia were incubated for $15 \mathrm{~min}$ at $37^{\circ} \mathrm{C}$ in Hank's balanced salt solution (without $\mathrm{Ca}^{2+}$ and $\mathrm{Mg}^{2+}$ ), with collagenase (type I, $1 \mathrm{mg} / \mathrm{ml}$; Sigma) and dispase (grade II, $2.4 \mathrm{mg} / \mathrm{ml}$; Boehringer Mannheim). They were then transferred to a similar solution containing only the dispase and triturated every $15 \mathrm{~min}$ with a Pasteur pipette for 3-4 hr. The cell suspension was then washed once with growth medium L-15 containing 10\% horse serum. The pellet was resuspended and centrifuged through a Percoll (Pharmacia) gradient (35\%) in order to separate neurons from non-neuronal cells. The neuronal suspension was then washed twice and plated on laminin-coated aclar (Allied Chemicals) coverslips $\left(30 \mu \mathrm{g} / \mathrm{ml}\right.$ in PBS overnight at $4^{\circ} \mathrm{C}$ ) in L-15 medium supplemented with sodium bicarbonate, vitamins, cofactors, penicillinstreptomycin, rat serum (5\%), and 7S NGF (10 nM). Cytosine arabinofuranoside (Ara-C; $10 \mu \mathrm{M}$; Sigma) was added to the culture medium for the first $4 \mathrm{~d}$ to kill any remaining dividing cells. The cultures were maintained in a humid atmosphere of $95 \%$ air, $5 \% \mathrm{CO}_{2}$ at $37^{\circ} \mathrm{C}$ and fed every 3-4 d with fresh growth medium. In some cultures, NGF was not added and sheep antiserum to mouse NGF was also added to the cultures at a dilution of $3: 10,000$ (a dilution of $1: 10,000$ blocks the effect of $10 \mathrm{nM} 7 \mathrm{~S}$ NGF when added to SCG cultures). To test for the lack of dependence on NGF for growth and survival, we removed NGF and added anti-NGF to some cultures that had received NGF for their first 2 weeks and allowed the cultures to continue to develop for an additional 2 weeks. The removal of NGF did not result in neuronal death. In contrast, SCG neurons all died within $3 \mathrm{~d}$ after NGF removal. In some cultures, the neurons were cocultured with their non-neuronal cells; for these cultures, the Percoll step was omitted and no Ara-C was added to the growth medium.

Immunocytochemistry. HM-2 (Sigma), a mouse monoclonal antibody against MAP2, was used to label dendrites. SMI31 (Sternberger-Meyer Immunochemicals), a mouse monoclonal antibody against phosphorylated forms of the M- and H-neurofilament subunits, was used to label axons. For double-labeling experiments (MAP2 and phosphorylated neurofilaments), we used a rabbit polyclonal antibody against MAP2 (R4) together with the SMI31 antibody. In some experiments, we immunostained our cultures with an antibody against MAP2a and $-2 b$ isoforms (AP-20, Sigma); the staining pattern was similar to the HM-2 and R4 antibodies, suggesting that MAP2c, which has been observed in axons (Tucker et al., 1988), is not present in neonatal nodose neurons or at least not in their axons. We also tested the antibody SMI32 (Sternberger-Meyer Immunochemicals) to stain nonphosphorylated neurofilaments in neuronal cell bodies and dendrites (Sternberger and Sternberger, 1983). Although we observed most of the immunoreactivity with this antibody in the cell bodies and dendrites, we could detect weak labeling in some axons; therefore, we preferred to use MAP2 antibodies as dendritic markers.

For all immunostaining experiments, cultures were fixed in $4 \%$ paraformaldehyde, $0.01 \%$ glutaraldehyde for $15 \mathrm{~min}$ in $0.1 \mathrm{M}$ phosphate buffer $(\mathrm{pH} 7.4)$ and rinsed three times with Tris-buffered saline $(5 \mathrm{~mm}$ Tris, $0.9 \% \mathrm{NaCl}, \mathrm{pH} 7.4$ ). Cells were permeabilized by incubating the cultures in $100 \%$ methanol at $-20^{\circ} \mathrm{C}$ for 15 min. After rinsing, the cells were incubated in Tris-buffered saline containing 5\% normal goat serum for $30 \mathrm{~min}$. In the same solution, the primary antibodies were added (HM-2, 1:5000; R4, 1:10,000; AP-20, 1:500; SMI31, 1:20,000) for $1 \mathrm{hr}$ at room temperature. After rinsing, the secondary antibodies (goat antimouse fluorescein isothiocyanate and goat anti-rabbit rhodamine isothiocyanate, 1:1000; Sigma) were added for $1 \mathrm{hr}$. Coverslips were rinsed and mounted on slides using Immuno Fluore mounting medium (ICN Immunobiologicals). The cells were examined by epifluorescence on a Leiss (Axiovert 35) microscope. Both the dendritic morphologies and the localization of HM-2, R4, AP-20, and SMI31 staining were similar in nodose and SCG neurons. However, we occasionally observed faint staining with the MAP2 antibodies in SCG axons, particularly before the extension of dendrites from SCG neurons. This is consistent with previous observations (Carceres et al., 1986; Kosik and Finch, 1987). In contrast, nodose neurons had no apparent staining in their axons at all times in culture.

Lucifer yellow injection. A stock of Lucifer yellow (lithium salt, Sigma) was prepared by dissolving $5 \mathrm{mg}$ of Lucifer yellow in $100 \mu \mathrm{l}$ of distilled water $(5 \%)$. This solution was then mixed with $200 \mathrm{~mm} \mathrm{LiCl}(1: 1)$. Microelectrodes filled with the Lucifer yellow solution (resistance of 50 $100 \mathrm{M} \Omega$ ) were used to impale neurons. When a resting potential of at least $-30 \mathrm{mV}$ was observed, Lucifer yellow was injected by pressure application. Lucifer yellow (potassium salt, Sigma) was also used to label neurons while performing whole-cell voltage-clamp experiments (see below). In these experiments, the Lucifer yellow was included in the pipette solution (see below) and diffused passively into the cell during the recordings.

Measurements of dendrite growth. In this article, we refer to thick, tapered, MAP2-positive processes that end locally, as dendrites. The proportion of neurons forming dendrites was measured by counting the number of neurons with and without dendrites on coverslips that were immunostained for MAP2. MAP2-positive processes with a length of at least one cell body diameter $(>35 \mu \mathrm{m})$ were scored as dendrites. The neurons were fixed and immunostained after 1,2 , and 3 weeks in culture, and the measurements represent the average of four different platings. The number of primary dendrites per neuron was determined for all neurons in a given culture that had dendrites. The mean dendritic length was measured by projecting the image from a Zeiss (Axiovert 35) microscope on a digitizing tablet and analyzed with SIGMASCAN software (Jandel Scientific). The length of each primary dendrite including the branches was measured on 30 neurons with dendrites in a given culture that were selected at random. We expressed the total dendritic growth as the product of the percentage of neurons with dendrites, the number of primary dendrites per neuron, and the mean length of dendrites.

$A C h$ sensitivity. ACh currents were measured electrophysiologically using whole-cell patch-clamp techniques (Hamill et al., 1981) as previously described (Mandelzys and Cooper, 1992). Briefly, recordings were performed at room temperature with a LIST EPC-7 amplifier. The pipette resistances were 2-6 $\mathrm{M} \Omega$, and pipettes were filled with intracellular medium ( $5 \mathrm{~mm} \mathrm{NaCl}, 80 \mathrm{~mm} \mathrm{KF}, 60 \mathrm{~mm} \mathrm{~K}$-acetate, $1 \mathrm{~mm} \mathrm{MgCl}_{2}$, $10 \mathrm{mM}$ HEPES (pH 7.4, adjusted with $\mathrm{KOH}$ ), $10 \mathrm{mM}$ EGTA, and 0.2 $\mathrm{mM} \mathrm{CaCl}_{2}$ (final concentration of $\sim 10^{-7} \mathrm{M}$ ) containing $0.5 \%$ Lucifer yellow (potassium salt). To measure ACh sensitivity on the neurons, we applied $50 \mu \mathrm{M}$ ACh for $2 \mathrm{sec}$ (ACh iodide, Sigma; dissolved in extracellular medium; see below) onto the cell body by pressure ejection from an electrode with a tip of $\sim 10 \mu \mathrm{m}$ diameter. The pipette tip was positioned at $20-30 \mu \mathrm{m}$ from the cell body, so that on application of light pressure (usually $20-30 \mathrm{kPa}$ ) the entire cell body and proximal processes were perfused. The cultures were continuously perfused with an extracellular medium [ $140 \mathrm{~mm} \mathrm{NaCl}, 5.4 \mathrm{~mm} \mathrm{KCl}, 2.8 \mathrm{~mm} \mathrm{CaCl}_{2}$, $10 \mathrm{~mm}$ HEPES (pH 7.4, adjusted with $\mathrm{NaOH}$ ), $5.6 \mathrm{~mm}$ glucose, $2 \mathrm{~mm}$ glutamine] at a rate of $1 \mathrm{ml} / \mathrm{min}$, and thereforc no buildup of $\mathrm{ACh}$ occurred in the recording chamber during the experiment. The neurons 

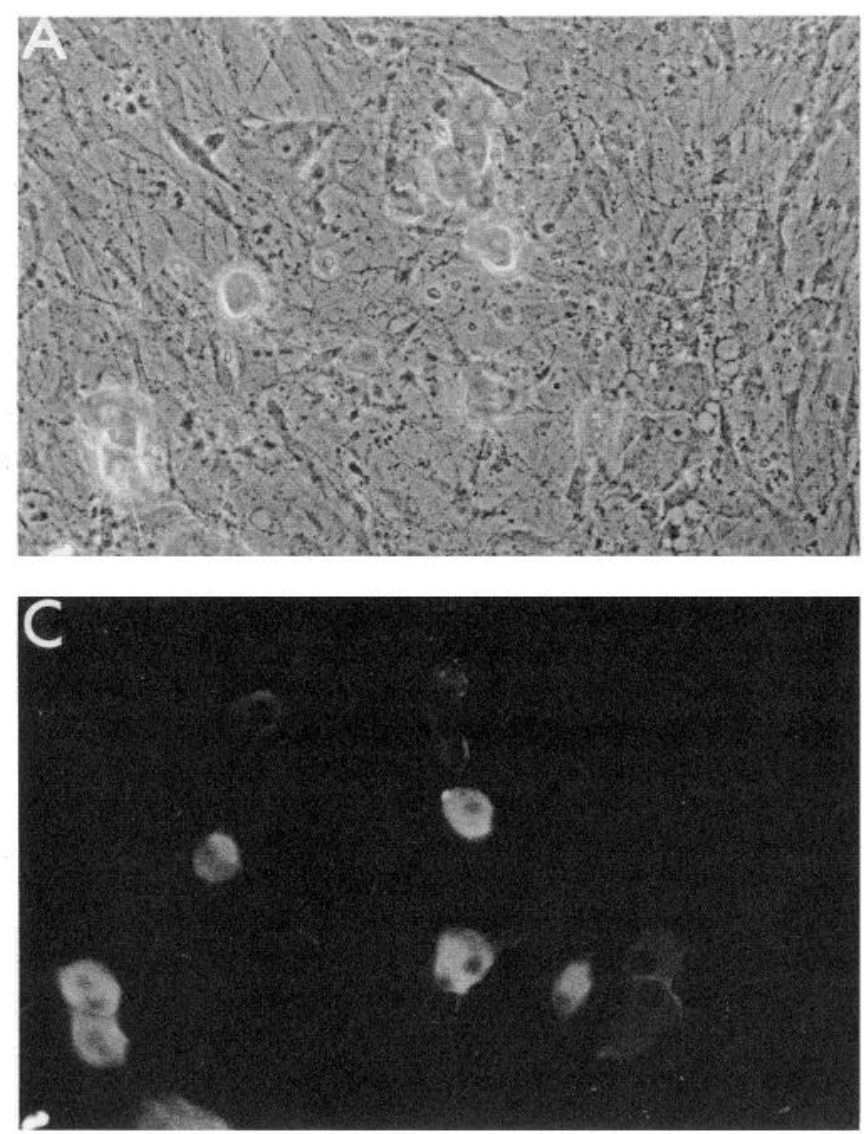

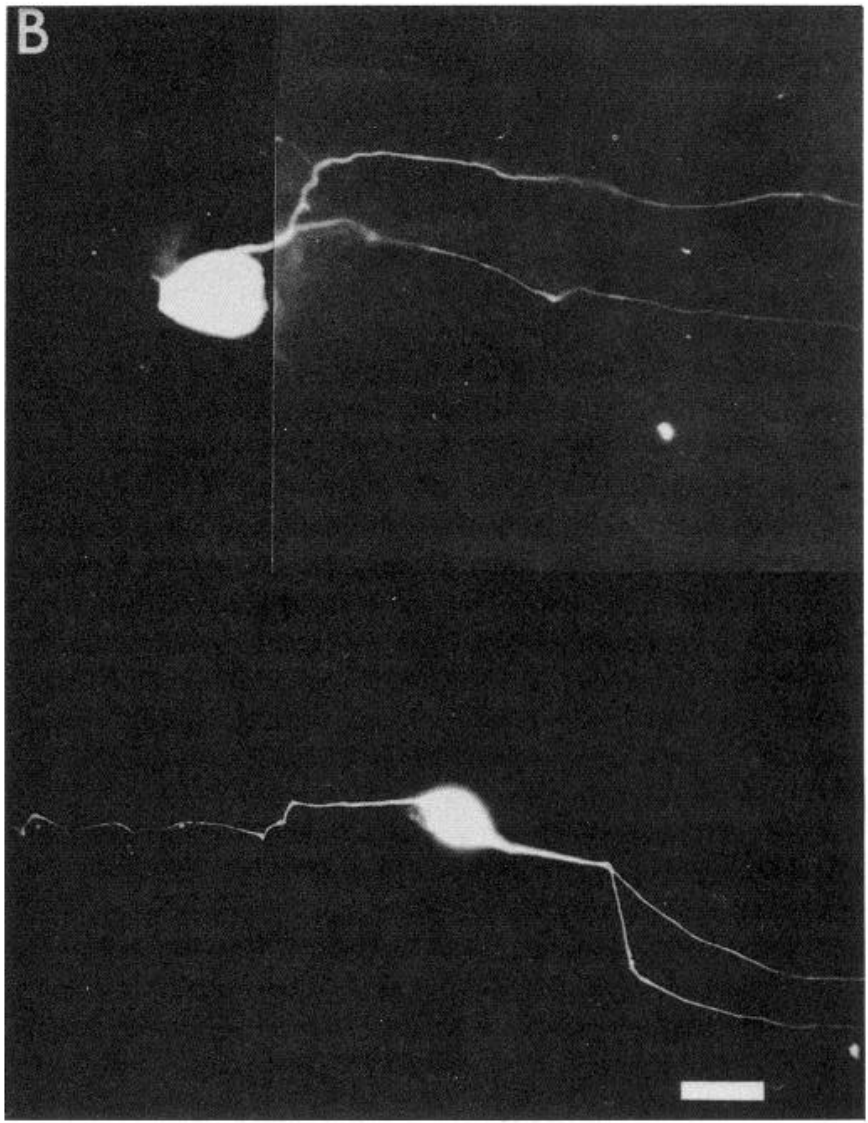

Figure 1. Nodose neurons in culture with ganglionic satellite cells. $A$, Phase-contrast photomicrograph of neonatal nodose neurons in culture for 3 weeks with satellite cells. $B$, Lucifer yellow injection of two nodose neurons from sister cultures. The upper neuron is unipolar with a single axon branching into two axons (this neuron is shown as a montage to allow better visualization of the axons). The lower neuron is bipolar with two axons emerging from the cell body. $C$, Fluorescent MAP2 (HM-2) staining of the same neurons as in A. Neurons lack MAP2-positive processes and many neurons have weakly immunostained cell bodies. Scale bar, $40 \mu \mathrm{m}$.

were voltage clamped at $-50 \mathrm{mV}$ during the application of $\mathrm{ACh}$ and the amplitude of the peak current evoked by ACh was measured. All ACh currents were normalized to cell capacitance by integrating the capacity current evoked by a $5 \mathrm{mV}$ hyperpolarizing voltage step from a holding potential of $-50 \mathrm{mV}$. The software for data acquisition and analysis was written by Mr. A. Sherman (Alembic Software, Montréal, Canada).

\section{Results}

Nodose neurons cocultured with ganglionic satellite cells are unipolar

In vivo, nodose neurons develop in close association with their ganglionic satellite cells and do not extend dendrites. Figure $1 \mathrm{~A}$ shows a typical phase micrograph of nodose neurons cocultured with their satellite cells for 3 weeks with NGF. The cell bodies of most neurons remained spherical or ovoid, although many appeared to have flattened onto the satellite cells. Most processes from these neurons are covered by the satellite cells and are difficult to resolve with phase optics. To investigate the morphologies of these neurons, the neurons were injected with $\mathrm{Lu}$ cifer yellow. Forty-six percent (29 of 63) of these neurons were unipolar after 2-3 weeks in culture (Fig. $1 B$, top). This unipolar morphology is similar to sensory neurons in vivo (see also Mudge, 1984). Twenty-nine percent (18 of 63) of the neurons had a bipolar morphology (Fig. $1 B$, bottom); this morphology is typical of undifferentiated sensory neuroblasts (Tennyson, 1965). Sixteen percent (10 of 63 ) of the neurons had three or more axons. Six percent ( 4 of 63) of the neurons had one or two short ( $\leq 35 \mu \mathrm{m}$ ), thick processes emerging from the cell body; two neurons, however, had thick processes that were $35-60 \mu \mathrm{m}$ in length, suggestive of dendrites. To investigate whether these processes had properties typical of dendrites, cultures were immunostained with antibodies to MAP2. Figure $1 C$ shows the same field as Figure $1 A$ but immunostained for MAP2. Of 1740 neurons examined, over $97 \%$ lacked processes with detectable MAP2 labeling.

\section{Nodose neurons develop dendrites in the absence of satellite cells}

Unlike nodose neurons cocultured with satellite cells, virtually all nodose neurons cultured without satellite cells acquire multipolar morphologies. Figure $2, A$ and $B$, shows two typical examples of neurons injected with Lucifer yellow that had developed for 3 weeks in culture in absence of satellite cells and in the presence of NGF. The neuron in Figure $2 A$ has three thick, tapered processes emerging from the cell body that are typical of dendrites, and has at least two thin processes of constant caliber, typical of axons. In contrast, all three processes emerging from the neuron in Figure $2 B$ appear axonal.

In addition, we distinguished dendrites from axons in these cultures by immunostaining them with antibodies to MAP2 and to phosphorylated neurofilaments (SMI31). Figure $3 A$ is a typical phase micrograph of three neonatal rat nodose neurons that 

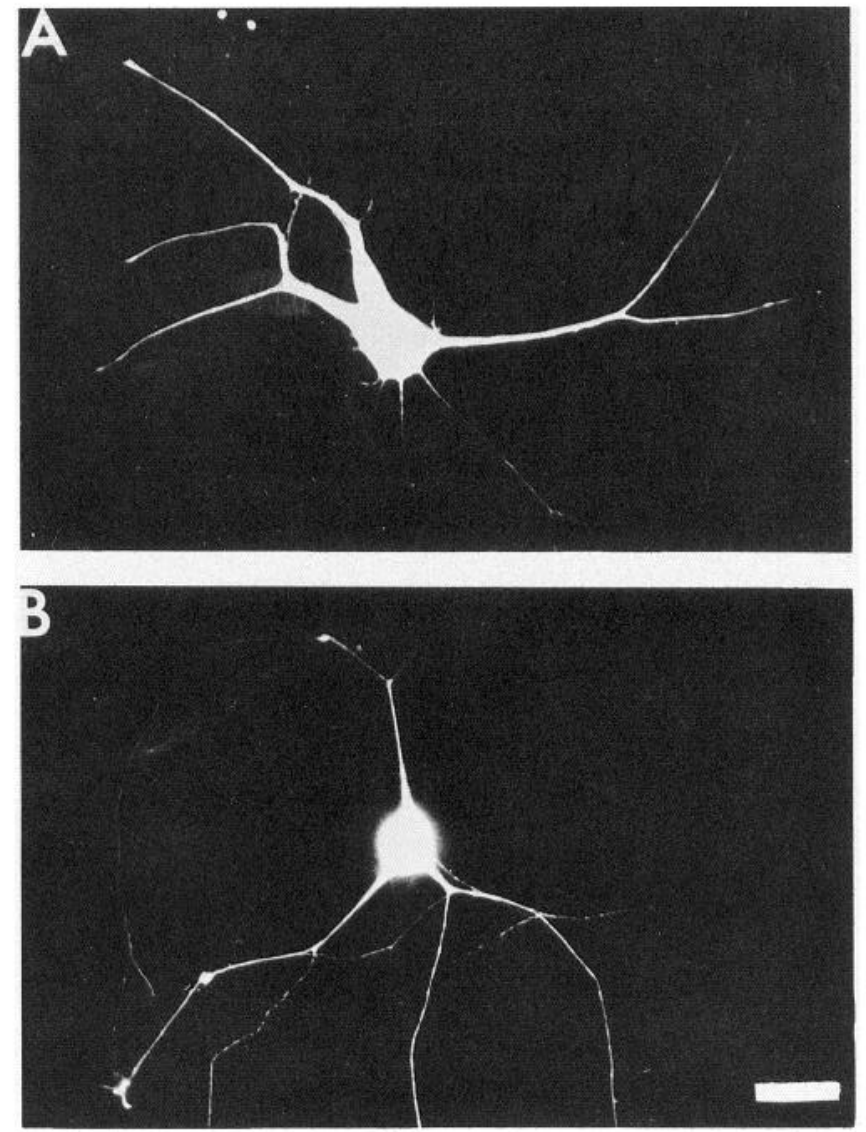

Figure 2. Nodose neurons in culture without satellite cells: Lucifer yellow injection of two typical nodose neurons that have developed for 3 weeks in absence of satellite cells. The neuron in $A$ has three thick, tapered processes that end locally, typical of dendrites, and at least two long, thin processes of constant caliber, typical of axons (which extend well beyond the field). The neuron in $B$ has a spherical cell body with three axonal processes but no dendrite-like processes. Scale bar, $40 \mu \mathrm{m}$.

have developed in culture for 3 weeks in absence of satellite cells and in the presence of NGF. Figure $3 B$ shows the same three neurons immunostained for MAP2. Two neurons have faint MAP2 labeling in their cell bodies but no MAP2-positive processes; the other neuron has three thick, MAP2-positive processes, typical of dendrites. Figure $3 C$ shows the same field immunostained with the SMI31 antibody. SMI31 labels most of the processes observed with phase optics except for the dendrites, which typically have axonal processes running over or along the side of them. Almost $25 \%$ (Table 1 ) of the neurons in these cultures had dendrites after 3 weeks in culture. Figures $4 A$ and $B$ are montages from one such culture that illustrates this proportion; Figure $4 B$ also shows that several of the neurons without dendrites in these cultures had weak or no detectable MAP2 staining in their cell bodies.

In addition to the proportion of neurons that had dendrites, we also measured the number of primary dendrites (dendrites

Figure 3. Double labeling for MAP2 and phosphorylated neurofilaments on nodose neurons after 3 weeks in culture without satellite cells and with NGF. $A$, Phase-contrast photomicrograph showing three neurons (one is out of the plane of focus). $B$, Fluorescent photomicrograph (rhodamine labeling) showing MAP2 staining with rabbit anti-MAP2 (R4). One neuron has three MAP2-positive processes, while the other
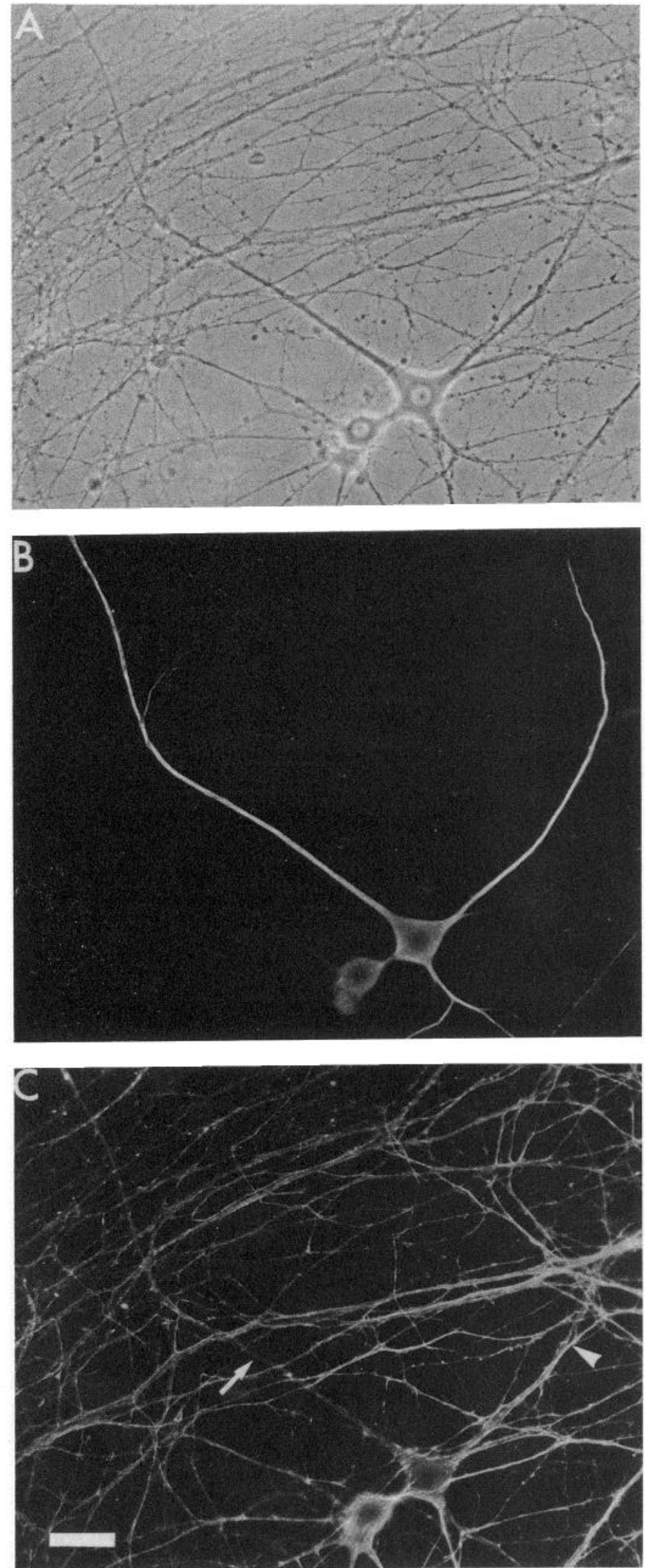

two have no MAP2-positive processes. $C$, Fluorescent photomicrograph (fluorescein labeling) showing phosphorylated neurofilament staining with mouse antibody SMI31. The network of axons seen in $A$ is brightly labeled, whereas the cell bodies and dendrites $(C$, arrow) have little if any staining. Note the thin axons running along and on top of the dendrite (arrowhead). Scale bar, $40 \mu \mathrm{m}$. 

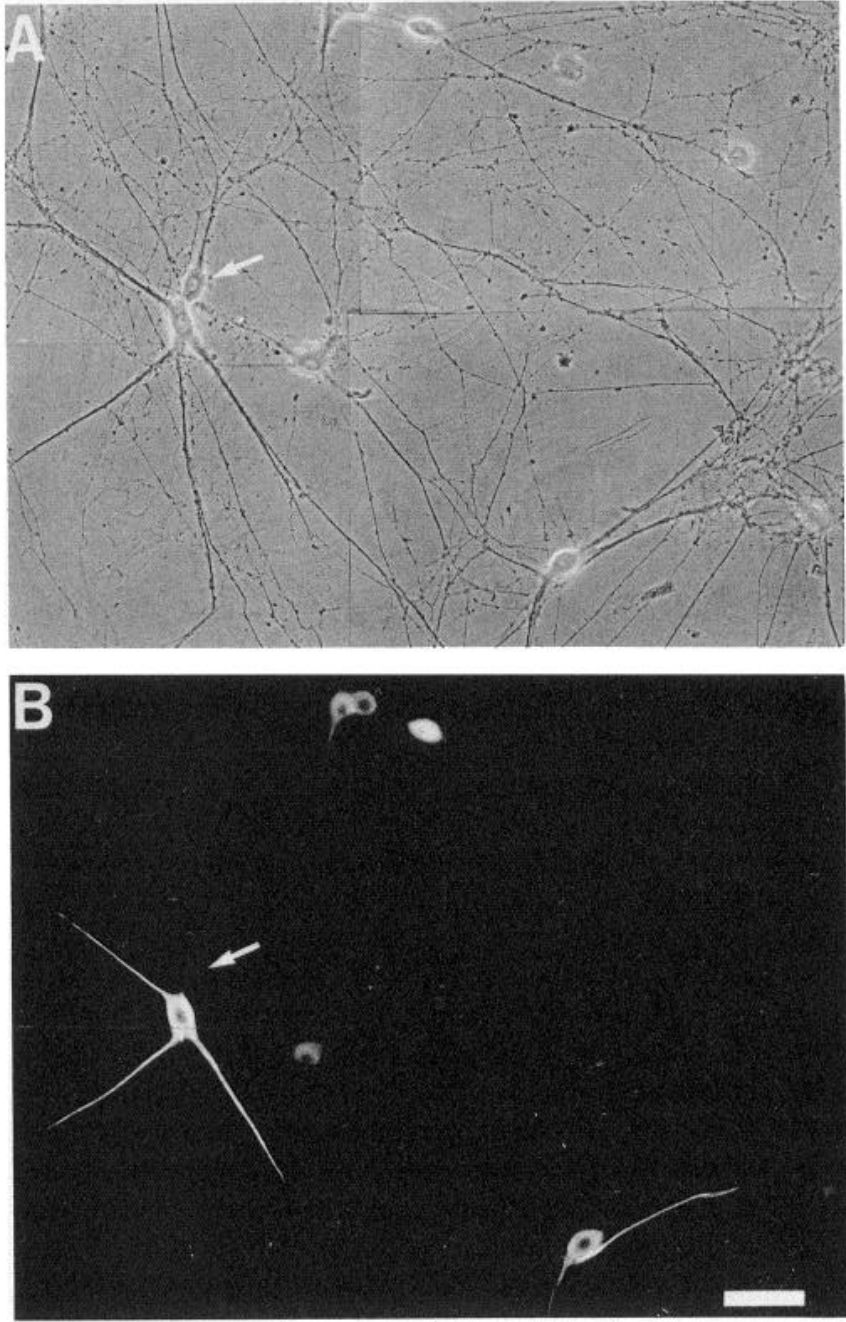

Figure 4. Nodose neurons with NGF. A, Phase-contrast photomicrograph of nodose neurons that have developed in culture for 3 weeks in absence of satellite cells and in presence of NGF. $B$, Fluorescent MAP2 (HM-2) staining of the same neurons as in $A$. Note that two neurons have long MAP2-positive processes, one neuron has a short MAP2positive process $(<35 \mu \mathrm{m})$, four neurons have MAP2 staining (of variable intensities) only in their cell bodies, and one neuron shows no staining for MAP2 (arrow). Scale bar, $80 \mu \mathrm{m}$.

extending directly from the cell bodies) of these neurons and the lengths of each primary dendrite to quantify further the extent of dendritic outgrowth in these cultures. Each parameter was measured at 1,2 , and 3 weeks after plating the neurons. Table 1 shows that, between 1 and 3 weeks in culture, the proportion of neurons extending dendrites increased from $10.6 \%$ to $24.1 \%$, that the average number of primary dendrites per neuron increased twofold, and that the mean dendritic length doubled.

\section{NGF stimulates dendrite formation}

The above results indicate that the control of dendrite initiation is subject to the removal of satellite cells; however, NGF was continually present in these cultures and Snider (1988) showed that NGF induces dendritic arborization on sympathetic neurons in vivo. NGF also promotes the expression of ACh currents on nodose neurons in culture (Mandelzys et al., 1990; Mandelzys and Cooper, 1992). Therefore, we tested whether NGF had an
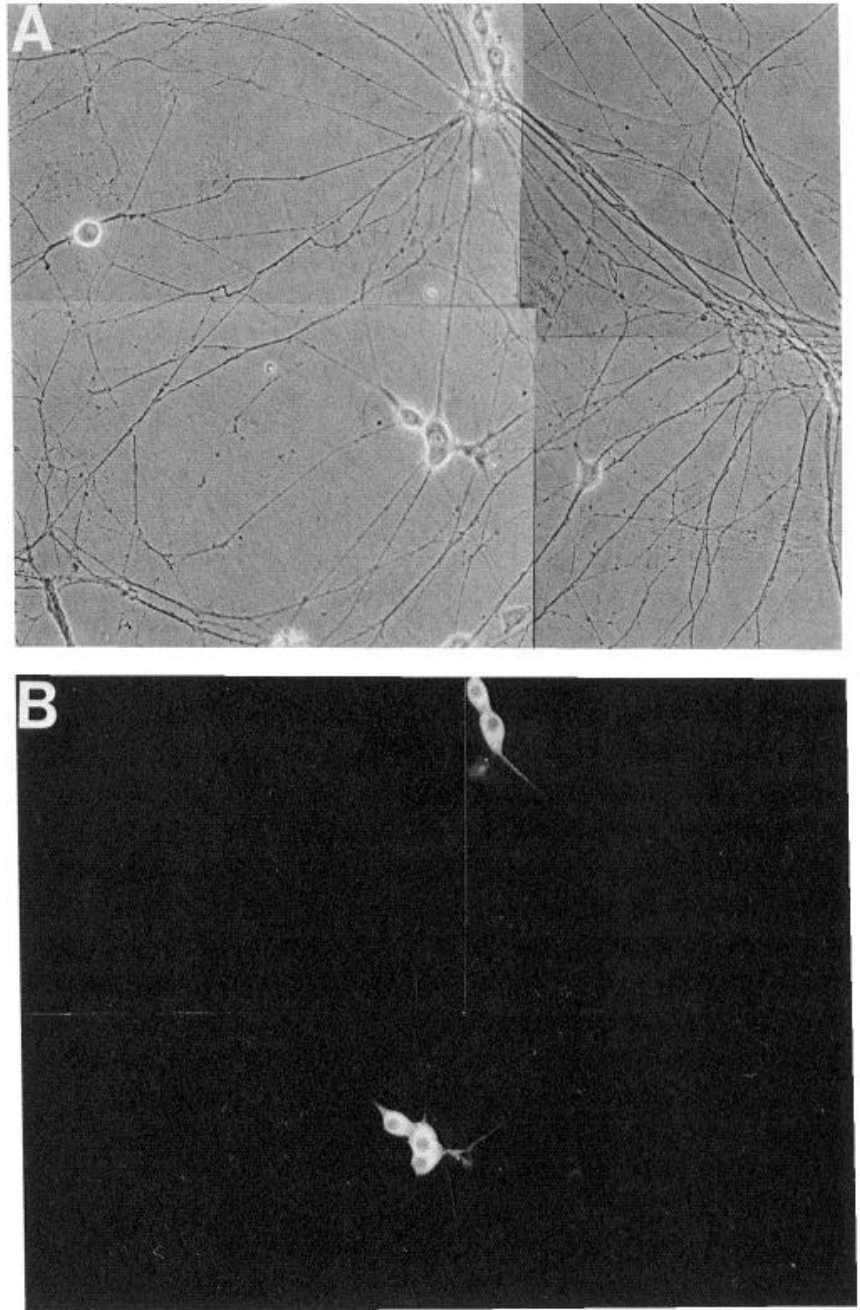

Figure 5. Nodose neurons without NGF. A, Phase-contrast photomicrograph of neurons in culture for 3 weeks without satellite cells and without NGF. $B$, Fluorescent MAP2 (HM-2) staining of the same neurons as in $A$. Note that fewer MAP2-positive processes are present (compare with Fig. 4) in these cultures. Scale is same as Figure 4.

effect on dendrite outgrowth once the satellite cells were removed from the cultures.

Figure $5 \mathrm{~A}$ shows a typical phase micrograph of nodose neurons that have developed in culture essentially devoid of other cell types and without NGF for 3 weeks. With phase optics, these cultures appear qualitatively similar to cultures grown in the presence of NGF (compare Fig. $4 A$ ), as neonatal rat nodose neurons do not need NGF for growth and survival in culture even though they possess high-affinity NGF receptors (Mandelzys et al., 1990). Figure $5 B$ shows the same field immunostained with an antibody to MAP2. In contrast to what was observed with cultures grown with NGF, these cultures showed significantly fewer MAP2-positive processes. The quantification of dendritic outgrowth in these cultures without NGF is presented in Table 2 . This table shows that after 3 weeks without NGF, less than $6 \%$ of the neurons extended dendrites and that the average number of primary dendrites per neuron as well as the mean dendritic length are both twofold less than on neurons exposed to NGF. Total dendritic growth, calculated as the product of the three dendritic parameters in Tables 1 and 2, was 17 fold greater in cultures with NGF (Fig. 6). 


\begin{tabular}{|c|c|c|c|c|}
\hline $\begin{array}{l}\text { Time in } \\
\text { culture } \\
\text { (weeks) }\end{array}$ & $\begin{array}{l}\text { Percentage of } \\
\text { neurons with } \\
\text { dendrites }^{a}\end{array}$ & $\begin{array}{l}\text { Number of } \\
\text { primary dendrites } \\
\text { per neuron }{ }^{b}\end{array}$ & $\begin{array}{l}\text { Mean length } \\
\text { of dendrites }\end{array}$ & $\begin{array}{l}\text { Number of axons } \\
\text { per neuron }{ }^{d}\end{array}$ \\
\hline 1 & $10.6 \pm 0.2(2314)$ & $1.4 \pm 0.1(246)$ & $86 \pm 8(66)$ & $2.9 \pm 0.1(14)$ \\
\hline 2 & $18.7 \pm 0.3(2503)$ & $2.0 \pm 0.2(469)$ & $108 \pm 7(92)$ & $2.7 \pm 0.1(31)$ \\
\hline 3 & $24.1 \pm 0.4(1753)$ & $2.4 \pm 0.2(422)$ & $155 \pm 9(93)$ & $2.7 \pm 0.1(48)$ \\
\hline
\end{tabular}

${ }^{a}$ Mean \pm SEM (total number of neurons from four different platings in parentheses).

${ }^{b}$ Mean \pm SEM (total neurons that had dendrites in parentheses).

c Mean \pm SEM (total dendrites from 30 neurons selected randomly in a given culture in parentheses).

${ }^{d}$ Mean \pm SEM (total neurons injected with Lucifer yellow in parentheses).

To test whether these effects of NGF on process outgrowth were specific for the initiation of dendrites and not axons, we filled individual neurons with Lucifer yellow and measured the number of axons emerging from the soma after 1, 2, and 3 weeks in culture. We classified thin processes of constant caliber that could be followed for several hundred microns as axons, whereas dendrites were classified as thick, tapered processes that ended locally (Bruckenstein and Higgins, 1988a,b; Tropea et al., 1988) (see Tables 1, 2). The results from these experiments indicate that the number of axons emerging from the somata did not increase significantly from week 1 to week 3 in culture, independent of the presence of NGF. This result suggests that the effects of NGF are specific for dendrite initiation and emphasizes that the initiation of dendrites on these neurons occurs after much longer times in culture than the initiation of axons (cf. Dotti et al., 1988).

\section{The ability of nodose neurons to develop dendrites is} developmentally regulated

The above results indicate that nodose neurons from $\mathrm{P} 1$ rats retain the ability to extend dendrites. To determine whether this ability is developmentally regulated, we cultured nodose neurons from P14 animals in the absence of satellite cells and with NGF. After 3 weeks in culture, less than 6\% (75 of 1347) of the P14 neurons had MAP2-positive processes. Of these, the mean number of dendrites per neuron was only $1.5 \pm 0.1(n=75)$ and the average length of each dendrite was $63 \pm 4 \mu \mathrm{m}(n=$

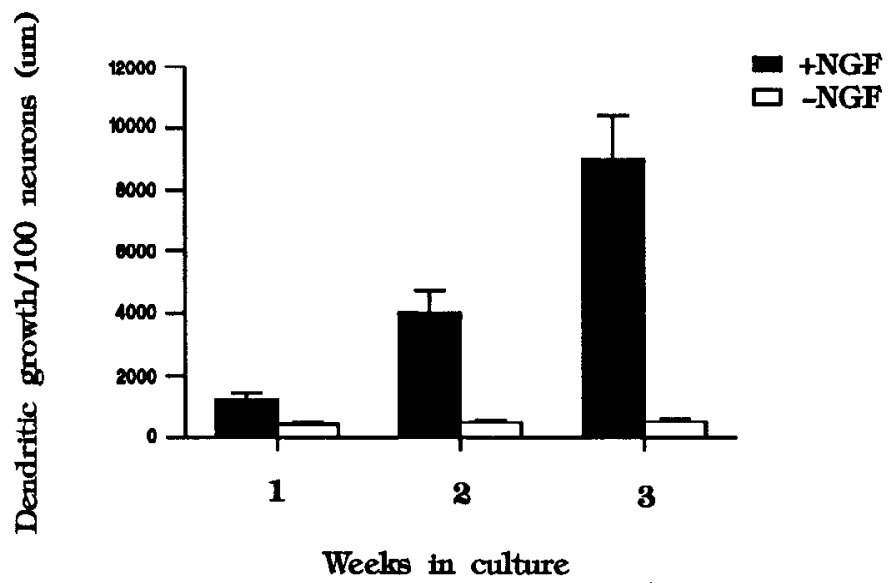

Figure 6. Total dendritic outgrowth by nodose neurons over time in culture. Total dendritic outgrowth was determined as the product of percentage of neurons with dendrites, number of primary dendrites per neuron, and mean length of dendrites, as given in Tables 1 and 2 . The values are normalized for 100 neurons. Error bars represent SEM.
47). These results indicate that nodose neurons from P14 animals have lost most of their ability to extend dendrites.

\section{Dendrite growth correlates with ACh sensitivity}

The removal of satellite cells and the addition of NGF also stimulate nodose neurons to express ACh currents (Cooper and Lau, 1986; Mandelzys et al., 1990; Mandelzys and Cooper, 1992). To investigate whether ACh current densities were different on neurons with dendrites from those that lacked dendrites, we simultaneously filled neurons with Lucifer yellow while recording from them electrophysiologically with whole-cell voltage-clamp techniques. Figure $7 A$ shows three neurons filled with Lucifer yellow, and below each are their respective whole-cell ACh currents. Neuron $\mathrm{A}$ has two long dendrites and a large (2300 pA) inward ACh-gated current; neuron B has two short dendrites and a smaller ( $300 \mathrm{pA}) \mathrm{ACh}$-gated current; neuron $\mathrm{C}$ has no dendrites and has no detectable $\mathrm{ACh}$-gated current. We recorded from over 30 identified neurons, and their morphologies fell into the three categories illustrated in Figure 7: class A neurons, with two or more long dendrites; class $B$ neurons, with one or two small dendrites; and class $C$ neurons, with no dendrites. Figure $7 B$ shows that the ACh current densities correlate with the extent of dendritic growth on nodose neurons.

\section{Discussion}

When neonatal sensory neurons from rat nodose ganglia develop in culture with their ganglionic satellite cells, many of these neurons acquire pseudo-unipolar morphologies similar to that of sensory neurons in vivo. Our results are similar to those of Mudge (1984), who reported that embryonic chick sensory neurons undergo a developmental transition from bipolar to pseudo-unipolar neurons when they develop in culture with Schwann cells. A major finding of this article is that removal of satellite cells allows nodose neurons to extend dendrites that are otherwise suppressed by these cells. These results indicate that neonatal sensory neurons are inherently able to extend dendrites, and that the initiation of dendrites on these neurons is controlled, in part, by satellite cells. The mechanism by which the satellite cells operate has not been determined. Interestingly, this satellite cell influence on sensory neurons is opposite to the influence of glial cells on neurons that normally extend dendrites in vivo (Tropea et al., 1988; Johnson et al., 1989; Clendening and Hume, 1990); in these latter studies, the presence of glial cells induces dendrite outgrowth. Therefore, with respect to dendrites, these results suggest that, in culture, glial cells influence neurons to acquire properties that they would normally have in vivo.

For neonatal nodose neurons developing in culture without 


\begin{tabular}{|c|c|c|c|c|}
\hline $\begin{array}{l}\text { Time in } \\
\text { culture } \\
\text { (weeks) }\end{array}$ & $\begin{array}{l}\text { Percentage of } \\
\text { neurons with } \\
\text { dendrites }^{a}\end{array}$ & $\begin{array}{l}\text { Number of } \\
\text { primary dendrites } \\
\text { per neuron }^{b}\end{array}$ & $\begin{array}{l}\text { Mean length } \\
\text { of dendrites }\end{array}$ & $\begin{array}{l}\text { Number of axons } \\
\text { per neuron }^{d}\end{array}$ \\
\hline 1 & $4.3 \pm 0.1(1839)$ & $1.3 \pm 0.1(79)$ & $77 \pm 6(40)$ & - \\
\hline 2 & $5.2 \pm 0.1(3023)$ & $1.2 \pm 0.1(158)$ & $81 \pm 6(42)$ & $2.9 \pm 0.1(20)$ \\
\hline 3 & $5.8 \pm 0.1(999)$ & $1.2 \pm 0.1(47)$ & $75 \pm 8(40)$ & $2.6 \pm 0.1(35)$ \\
\hline
\end{tabular}

${ }^{a}$ Mean \pm SEM (total number of neurons from four different platings in parentheses).

${ }^{b}$ Mean \pm SEM (total neurons that had dendrites in parentheses).

' Mean \pm SEM (total dendrites from 30 neurons selected randomly in a given culture in parentheses).

${ }^{d}$ Mean \pm SEM (total neurons injected with Lucifer yellow in parentheses).

satellite cells, we showed that NGF causes a 17-fold increase in total dendritic outgrowth. Snider (1988) showed that treatment of neonatal rats with NGF for 1-2 weeks increased the number of primary dendrites on SCG neurons, as well as increased the length and branching of existing dendrites, an effect that persisted for many months (Ruit and Snider, 1991). Our results on the effects of NGF are consistent with Snider's in vivo obser- vations. We found that NGF caused an increase in the number of primary dendrites, as well as an increase in the length of each dendrite. Importantly, we observed that NGF also caused a fivefold increase in the number of neurons extending dendrites, such that after 3 weeks in culture, almost $25 \%$ of the neurons extended dendrites. These results suggest that NGF causes neurons to initiate dendrites de novo. The fact that not all nodose
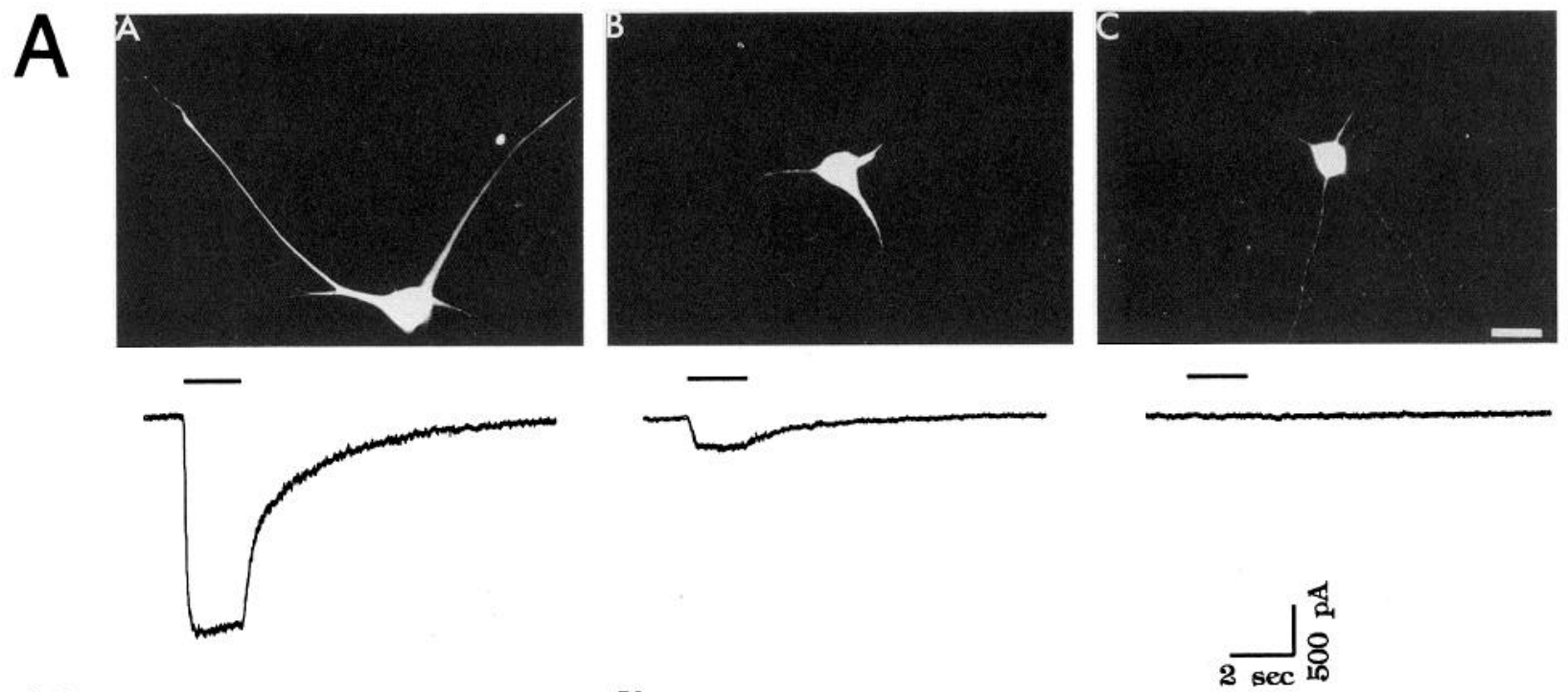

B

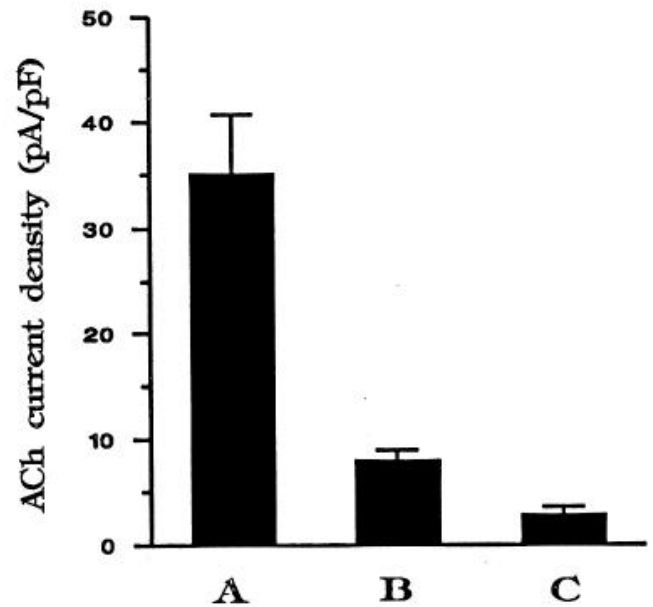

Figure 7. ACh sensitivity of nodose neurons with and without dendrites. $A$ shows three Lucifer yellow-filled neurons that have developed in culture for 2 weeks. Neuron $A$ has two long dendrite-like processes; neuron $B$ has two short dendrite-like processes; neuron $C$ has no dendrite-like processes. Scale bar, $40 \mu \mathrm{m}$. Under each neuron is shown its respective ACh-gated inward current evoked by pressure application of $50 \mu \mathrm{M}$ ACh for $2 \sec$ (horizontal bar). B shows the ACh current densities $(\mathrm{pA} / \mathrm{pF})$ on the three classes of neurons shown in $A$ : class $\mathrm{A}(n=12), \mathrm{B}(n=9)$, and $\mathrm{C}(n=12)$. The values represent the means \pm SEM. 
neurons extend dendrites suggests that other factors are involved, such as the developmental stage of the neurons when removed for culture. In this context, we found that less than $6 \%$ of nodose neurons could extend dendrites when removed from P14 animals.

It seems unlikely that these results are due to selective survival of a subpopulation of NGF-sensitive neurons because (1) 85$90 \%$ of neonatal rat nodose neurons do not need NGF for survival in culture (Mandelzys et al., 1990) and (2) addition of antiNGF to the cultures after 2 weeks had no effect on the number of neurons whereas adding anti-NGF to cultures of sympathetic neurons (which are NGF dependent) caused complete neuronal death in $3 \mathrm{~d}$.

In contrast to nodose neurons in chick, which do not have high-affinity NGF receptors (Lindsay and Rohrer, 1986), Mandelzys et al. (1990) showed that neonatal rat nodose neurons express high-affinity NGF receptors in culture in the absence of satellite cells, and Richardson et al. (1986) showed that, in adult rat, some nodose neurons have high-affinity NGF receptor. As it has been recently shown that the proto-oncogene product $t r k$ is involved in high-affinity NGF binding (Kaplan et al., 1991), one might expect that nodose neurons in rodents express trk mRNA. However, Martin-Zanca et al. (1990) reported that trk mRNA is not present in embryonic mouse nodose. If the pattern of $t$ rk expression is the same in rat and mouse, then these results might suggest that trk expression in nodose neurons increases during development. Another possibility, not necessarily exclusive of the first, is that some neonatal rat nodose neurons lack trk and only express $t r k$ in culture without satellite cells.

The MAP2 gene is alternatively spliced into three different transcripts encoding for two high-molecular-weight forms, MAP2 $a$ and MAP2b, and a low-molecular-weight form, MAP2c (Garner and Matus, 1988). MAP2a and $\mathbf{- 2 b}$ are almost exclusively localized in cell bodies and dendrites (Goedert et al., 1991), whereas MAP2c is found in axons during development (Tucker et al., 1988). It appears likely that MAP2a and $-2 \mathrm{~b}$ play an essential role for the growth and maintenance of dendrites, presumably by stabilizing microtubules or by cross-bridging them to neurofilaments (Hirokawa et al., 1988; Matus, 1988; Goedert et al., 1991). The degree of phosphorylation of MAP2a and -b could affect the cross-bridging of microtubules to other cytoskeletal elements allowing dendritic growth (Olmsted, 1986). In this context, it is conceivable that NGF may be involved in the regulation of MAP2 phosphorylation. Indeed, there is good evidence that $t r k$, which is involved in high-affinity NGF binding, acts via a tyrosine kinase pathway (Kaplan et al., 1991; Nebreda et al., 1991). Furthermore, it has been shown that NGF stimulates the tyrosine phosphorylation of several intracellular proteins including MAP2 kinase (Schanen-King et al., 1991), which itself phosphorylates MAP2 (Landreth et al., 1990; Miyasaka et al., 1990).

Independent of its effect on phosphorylation, NGF could achieve its effects on neonatal nodose neurons through other mechanisms, such as de novo gene expression of various proteins necessary for the initiation and growth of dendrites. In this regard, we observed that in cultures of nodose neurons, a significant number of somata had weak or no detectable staining for MAP2. As nodose neurons do not extend dendrites in vivo, this finding suggests that many nodose neurons do not express MAP2. If so, it raises questions about the relationship between the expression of MAP2 and the extension of dendrites: in the cascade of events that lead to the initiation of dendrites, does
MAP2 expression precede the development of dendrites, or is MAP2 expression concomitant with dendrite initiation, or perhaps even delayed until the dendrite emerges from the soma? Our preliminary data suggest that the number of MAP2-positive neurons increases in culture over time, even though many of these neurons do not extend dendrites. This observation may suggest that MAP2 expression precedes dendrite initiation and provides additional evidence that MAP2 is essential for dendrite growth and maintenance (Matus, 1988). On the other hand, Bruckenstein and Higgins (1988a) found that embryonic day 20-21 rat SCG neurons, cultured without other cell types and without serum, do not extend dendrites, even though all neurons expressed MAP2. Their observations suggest that other factors, in addition to MAP2, are involved in the initiation of dendrites, such as extracellular matrix proteins. Higgins et al. (1988) also observed that under the same conditions, some axons immunostained for MAP2. We did not observe MAP2 staining of axons in cultures of neonatal nodose neurons.

Neonatal rat nodose neurons form functional synapses among one another when they develop in culture without ganglionic satellite cells and with NGF; the postsynaptic receptors at these synapses have a nicotinic pharmacology (Cooper, 1984). Under these same conditions, many nodose neurons develop high nicotinic ACh current densities (Mandelzys and Cooper, 1992). In the present study, we demonstrated in combined morphological and electrophysiological experiments that neurons extending several long dendrites have high ACh current densities whereas neurons that lacked dendrites had small or no detectable ACh currents. These results link together the developmental expression of dendrites, a major structural component of a postsynaptic neuron, with the expression of the postsynaptic receptors. The temporal expression of these two features suggests that they are coordinatcly rcgulated, and may suggest that high $\mathrm{ACh}$ receptor densities on dendrites serve as sites for synaptic contacts.

Lastly, when neonatal nodose neurons develop in culture without satellite cells and with NGF, they acquire some properties that are more typical for autonomic neurons than for sensory neurons. One possibility is that many neonatal nodose are not fully committed to their adult sensory phenotype, and that in the absence of satellite cells they can still acquire new properties. In fact, neurons that develop for a further 2 weeks in vivo surrounded by satellite cells lose this ability to extend dendrites or express large ACh currents (Mandelzys and Cooper, 1992). This may indicate that, by 2 weeks of postnatal development, these neurons have become committed to their adult phenotype.

\section{References}

Bartlett WP, Banker GA (1984a) An electron microscopy study of the development of axons and dendrites by hippocampal neurons in culture. I. Cells which develop without intercellular contacts. J Neurosci 4:1944-1953.

Bartlett WP, Banker GA (1984b) An electron microscopy study of the development of axons and dendrites by hippocampal neurons in culture. II. Synaptic relationships. J Neurosci 4:1954-1965.

Black MM, Baas PW (1989) The basis of polarity in neurons. Trends Neurosci 12:211-214.

Bruckenstein DA, Higgins D (1988a) Morphological differentiation of embryonic rat sympathetic neurons in tissue culture. I. Conditions under which neurons form axons but not dendrites. Dev Biol 128: 324-336.

Bruckenstein DA, Higgins D (1988b) Morphological differentiation of embryonic rat sympathetic neurons in tissue culture. II. Serum promotes dendritic growth. Dev Biol 128:337-348.

Carceres A, Binder LI, Payne MR, Bender P, Rebhun L, Steward O 
(1984) Differential subcellular localization of tubulin and the microtubule-associated protein MAP2 in brain tissue as revealed by immunocytochemistry with monoclonal hybridoma antibodies. J Neurosci 4:394-410.

Carceres A, Banker G, Binder L (1986) Immunocytochemical localization of tubulin and microtubule-associated protein during development of hippocampal neurons in culture. J Neurosci 6:714-722.

Chamak R, Prochiantz A (1989) Influence of extracellular matrix proteins on the expression of neuronal polarity. Development 106:483491.

Clendening B, Hume RI (1990) Cell interactions regulates dendritic morphology and response to neurotransmitters in embryonic chick sympathetic preganglionic neurons in vitro. J Neurosci 10:3992-4005.

Cooper E (1984) Synapse formation among developing sensory neurones from rat nodose ganglia grown in tissue culture. J Physiol (Lond) 351:263-274.

Cooper E, Lau M (1986) Factors affecting the expression of acetylcholine receptors on rat sensory neurones in culture. J Physiol (Lond) 377:409-420.

Dotti CG, Sullivan CA, Banker GA (1988) The establishment of polarity by hippocampal neurons in culture. J Neurosci 8:1454-1468.

Garner CC, Matus A (1988) Different forms of microtubule-associated protein 2 are encoded by separated mRNA transcripts. J Cell Biol 106:779-783.

Goedert M, Crowther RA, Garner CC (1991) Molecular characterization of microtubule-associated protein tau and MAP2. Trends Neurosci 14:193-199.

Hamill OP, Marty A, Neher E, Sakmann B, Sigworth FJ (1981) Improved patch-clamp techniques for high resolution current recording from cells and cell-free membrane patches. Pfluegers Arch 391:85100 .

Higgins D, Waxman A, Banker G (1988) The distribution of microtubule-associated protein 2 changes when dendritic growth is induced in rat sympathetic neurons in vitro. Neuroscience 24:583-592.

Hirokawa N, Hisanaga S, Shiomura Y (1988) MAP2 is a component of crossbridges between microtubules and neurofilaments in the neural cytoskeleton: quick-freeze, deep-etch immunoelectron microscopy and reconstitution studies. J Neurosci 8:2769-2779.

Johnson MI, Higgins D, Ard MD (1989) Astrocytes induces dendritic development in cultured sympathetic neurons. Dev Brain Res 47: 289-292.

Kaplan DR, Hempstead BL, Martin-Zanca D, Chao MV, Parada LF (1991) The trk proto-oncogene product, a signal transducing receptor for nerve growth factor. Science 252:554-558.

Kleiman R, Banker G, Steward O (1990) Differential subcellular localization of particular mRNAs in hippocampal neurons in culture. Neuron 5:821-830.

Kosik KS, Finch EA (1987) MAP2 and tau segregate into dendritic and axonal domains after the elaboration of morphologically distinct neurites, an immunocytochemical study of cultured rat cerebellum. J Neurosci 7:3142-3153.

Landreth GE, Smith DS, McCabe C, Gittinger C (1990) Characterization of a nerve growth factor-stimulated protein kinase in $\mathrm{PCl} 2$ cells which phosphorylates microtubule-associated protein 2 and pp250. J Neurochem 55:514-523.

Lein PJ, Higgins D (1989) Laminin and a basement membrane extract have different effects on axonal and dendritic outgrowth from embryonic rat sympathetic neurons in vitro. Dev Biol 136:330-345.

Lieberman AR (1976) Sensory ganglia. In: The peripheral nerve (Landon DN, ed), pp 188-278. London: Chapman and Hall.

Lindsay RM, Rohrer H (1985) Placodal sensory neurons in culture: nodose ganglion neurons are unresponsive to NGF, lack NGF recep- tors but are supported by liver-derived neurotrophic factor. Dev Biol 112:30-48.

Mandelzys A, Cooper E (1992) The effect of ganglionic satellite cells and NGF on nicotinic acetylcholine receptor expression on rat sensory neurons. J Neurophysiol 67:1213-1221.

Mandelzys A, Cooper E, Verge MK, Richardson PM (1990) Nerve growth factor induces functional nicotinic acetylcholine receptors on rat sensory neurons in culture. Neuroscience 37:523-530.

Martin-Zanca D, Barbacid M, Parada LF (1990) Expression of the $t r k$ protooncogene is restricted to the sensory cranial and spinal ganglia of neural crest origin in mouse development. Genes Dev 4:683-694.

Matus A (1988) Microtubulc-associated protcins: their potential role in determining neuronal morphology. Annu Rev Neurosci 11:29-44.

McFarlane S, Cooper E (1992) Postnatal development of voltage gated $\mathrm{K}$ currents on rat sympathetic neurons. J Neurophysiol 67:12911300.

Miyasaka T, Chao MV, Sherline P, Saltied AR (1990) Nerve growth factor stimulates a protein kinase in PC-12 that phosphorylates microtubule-associated protein-2. J Biol Chem 265:4730-4735.

Mudge AW (1984) Schwann cells induce morphological transformation of sensory neurones in vitro. Nature 309:367-369.

Nebreda AR, Martin-Zanca D, Kaplan DR, Parada LF, Santos E (1991) Induction by NGF of meiotic maturation of Xenopus oocytes expressing the trk proto-oncogene product. Science 252:558-561.

Olmsted JB (1986) Microtubule-associated proteins. Annu Rev Cell Biol 2:421-457.

Pannese E (1981) The satellite cells of the sensory ganglion. Adv Anat Embryol Cell Biol 65:1-111.

Peng I, Binder LI, Black MM (1986) Biochemical and immunological analyses of cytoskeletal domains of neurons. J Cell Biol 102:252-262.

Peters A, Palay SL, Webster H (1991) The fine structure of the nervous system: the neurons and supporting cells, 3d ed. New York: Oxford UP.

Purves D, Snider WD, Voyvodic JT (1988) Trophic regulation of nerve cell morphology and innervation in the autonomic nervous system. Nature 336:123-128.

Richardson PM, Verge VMK, Riopelle RJ (1986) Distribution of neuronal receptors for nerve growth factor in rat. J Neurosci 6:23122321.

Ruit KG, Snider WD (1991) Administration or deprivation of nerve growth factor during development permanently alters neuronal geometry. J Comp Neurol 314:106-113.

Schanen-King C, Nel A, Williams LK, Landreth G (1991) Nerve growth factor stimulates the tyrosine phosphorylation of MAP2 kinase in PC12 cells. Neuron 6:915-922.

Schilling K, Dickinson MH, Connor JA, Morgan JI (1991) Electrical activity in cerebellar cultures determines Purkinje cell dendritic growth patterns. Neuron 7:891-902.

Snider WD (1988) Nerve growth factor enhances arborization of sympathetic ganglion cells in developing mammals. J Neurosci 8:26282634

Sternberger LA, Sternberger NH (1983) Monoclonal antibodies distinguish phosphorylated and non-phosphorylated forms of neurofilaments in situ. Proc Natl Acad Sci USA 80:6126-6130.

Tennyson VM (1965) Electron microscopic study of the developing neuroblast of the dorsal root ganglion of the rabbit embryo. J Comp Neurol 124:267-318.

Tropea M, Johnson MI, Higgins D (1988) Glial cells promote dendritic development in rat sympathetic neurons in vitro. Glia 1:380-392.

Tucker RP, Binder LI, Matus AI (1988) Neuronal microtubule-associated proteins in the embryonic avian spinal cord. J Comp Neurol 271:44-55. 